\title{
Multi-Source Data Integration to Investigate a Deep-Seated Landslide Affecting a Bridge
}

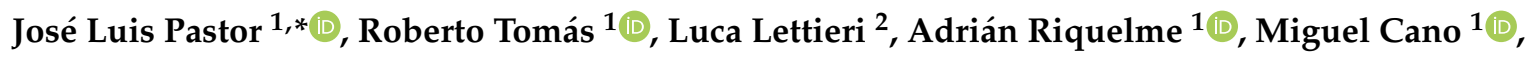 \\ Donato Infante ${ }^{3}$, Massimo Ramondini ${ }^{2}$ and Diego Di Martire ${ }^{4} \mathbb{D}$ \\ 1 Department of Civil Engineering, University of Alicante, 03690 Alicante, Spain \\ 2 Department of Civil, Architectural and Environmental Engineering, Federico II University of Napoli, \\ 80125 Napoli, Italy \\ 3 SINTEMA Engineering, viale Kennedy 5, 80125 Napoli, Italy \\ 4 Department of Earth, Environmental and Resources Sciences, Federico II University of Napoli, \\ 80125 Napoli, Italy \\ * Correspondence: joseluis.pastor@ua.es; Tel.: +34-965-90-3400 (ext. 1167)
}

Received: 13 June 2019; Accepted: 9 August 2019; Published: 12 August 2019

check for updates

\begin{abstract}
The integration of data from different sources can be very helpful in understanding the mechanism, the geometry, the kinematic, and the area affected by complex instabilities, especially when the available geotechnical information is limited. In this work, the suitability of different techniques for the study of a deep-seated landslide affecting a bridge in Alcoy (Spain) is evaluated. This infrastructure presents such severe damage that has rendered the bridge unusable, which prevents normal access to an important industrial area. Differential SAR Interferometry (DInSAR) and terrestrial Light Detection and Ranging (LiDAR) remote sensing techniques have been combined with ground displacement monitoring techniques, such as inclinometers and conventional geological and geotechnical investigation, electrical-seismic tomography, damage, and topographic surveys, to determine the boundaries, mechanism, and kinematics of the landslide. The successful case study that is illustrated in this work highlights the potential and the need for integrating multi-source data for the optimal management of complex landslides and the effective design of remedial measurements.
\end{abstract}

Keywords: DInSAR; multi-source integration; rotational landslide; structural damage; bridge

\section{Introduction}

In many cases, geotechnical information does not allow for performing a comprehensive characterization of an instability, especially when this information is limited. This can lead to deficient designs of stabilization measures. When this occurs, a combined use of different techniques can be of great help in overcoming the lack of available geotechnical information. In the past, many researchers demonstrated that the integration of different techniques allows a better understanding of the instabilities process under investigation [1-4]. A multi-method characterization of an active landslide in France was done by Fressard et al. [5], combining geophysical methods, aerial-photo images analysis, and geotechnical surveys. Refice et al. [6] integrated persistent scatterer interferometry and ground data for landslide monitoring in southern Italy. Additionally, the multidisciplinary approach that was performed by Tomás et al. [7] for the study of a complex lateral spreading allowed for its identification and characterization.

Amongst the complementary techniques that can be employed, geophysical methods are widely used for landslides research. Properties, such as layering, degree of fracturing, and stiffness of soils and rocks, can be characterized by the application of seismic tomography due to the velocity contrast induced between stable bedrock and unstable mass [8,9]. Electrical methods are also very useful for 
this purpose, because of the lowering of the resistivity in the landslide body due to the weathering of the minerals and the increasing of the moisture content on the slip surface [9]. Therefore, geophysical method are widely used for landslide characterization [9-13].

Satellite monitoring, and more specifically Differential Interferometry Synthetic Aperture Radar (DInSAR), has been employed in recent years to assess slope stability in urban areas [14-18]. This technique allows obtaining information about displacements of the ground surface with millimetre accuracy, being of great help to define the boundaries, intensity and state of activity of the landslide.

Terrestrial Laser Scanner or Terrestrial Light Detection and Ranging (LiDAR) has also been successfully used for landslide monitoring and for defining the boundaries of active landslides [19-23], being able to identify small deformations by repeating terrestrial laser scanning surveys.

Topographic survey and ground control points are traditional surveying techniques that are extensively used with very good results for landslide monitoring [24,25]. Three-dimensional coordinates are obtained for each monitoring point at every field survey. The movement of the control points can be assessed by a comparison between field surveys performed on different dates. In some studies, topography has given more accurate results for monitoring purposes than other means, such as LiDAR [19]. Damage surveys have also been used as a complementary technique in previous landslides [26,27], especially in urban areas, where cracks can be more accurately measured. In fact, maps showing the level of damage affecting structures and infrastructures could be a useful tool for detecting hazardous situations and preventing construction in landslide-prone areas [28].

In the present work, all of the previously mentioned techniques have been used to study a deep-seated landslide affecting a bridge in the city of Alcoy, Alicante Province (SE Spain), proving the usefulness of the combination of different techniques. This bridge is the main road leading to an important industrial area of the city. The only alternative way of connecting the city and the industrial area is by crossing a near ravine where the truck traffic is limited. The bridge that is affected by the landslide is $80 \mathrm{~m}$ long and presents a curved path. A reinforced concrete deck slab was built over the five precast beams between adjacent piers. It has three intermediate piers, with three columns for each pier, being supported by a cast-in-place pile foundation with six piles for every pier. Every pile has a total length of $15.0 \mathrm{~m}$ and a diameter of $1.0 \mathrm{~m}$. This infrastructure presents such severe damage that has rendered the bridge unusable.

As discussed earlier, the geotechnical information by itself does not provide enough understanding of the instability, and only limited geotechnical information is available for characterizing the mechanism of the landslide. Therefore, a multi-source data integration approach was employed to understand the mechanism of the slope instability and delineate the boundaries of the landslide.

\section{Geological Settings and History of the Slope}

The city of Alcoy is located on the upper basin of the Serpis river. This basin belongs to the Pre-Betic area, which is the most northerly Alpine zone forming the Betic Cordilleras of Southern Spain. The Pre-Betic zone is composed of folded and faulted Mesozoic and Tertiary rocks, where the Triassic rocks are strongly deformed over the Keuper formation that covers the Hercynian basement [29]. Two main facies are present in this area, massive competent limestones and highly incompetent marl-limestones [30].

The area of Alcoy presents high landslide susceptibility [29,31-33]. The first recorded instability on the slope under investigation was in September 1989 after heavy rainfalls. At this time, the bridge was not built yet and the industrial area was connected to the city by a road that was built on the slope. Later, in 1994, new pieces of evidence of instabilities were observed on the surface of the slope. In 2001, a water pipe was built at the side of the road, connecting the industrial area with the city broke. Afterwards, in January 2002, large tension cracks, which were up to approximately $80 \mathrm{~m}$ long, were observed on the surface of the slope. The bridge was built in 2004 over the cracks, trying to avoid the instability area. Moreover, the water pipe was rebuilt hanging from the deck of the bridge. No monitoring system was designed to control the slope, despite the instability that was observed since 1989 and the uncertain design conditions. Probably, long-term monitoring of the slope would have 
redounded to the benefit of risk mitigation [34,35]. In 2011, the Alcoy City Council was alerted that an industrial building located at the toe of the slope was affected by a landslide. After inspecting the slope, it was detected that the bridge was also damaged by the landslide, starting, at this point, new investigations to know the extension of the instability.

\section{Methodology}

\subsection{Geological and Geotechnical Characterization}

A detailed geological map of the study area was performed based on previously existing works $[29,33,36]$ and in situ surveys. The geotechnical properties of the area were investigated in two different campaigns. A first geotechnical survey was developed in 2002 before the construction of the bridge, consisting of three boreholes about $15 \mathrm{~m}$ depth (B-3 to B-5 in Figure 1). A second survey was performed between June 2012 and July 2013 after the slope instability was detected, including two new boreholes with a maximum depth of $40 \mathrm{~m}$ (B-1 to B-2 in Figure 1). From the five boreholes, 42 soil classifications tests (i.e., sieve analysis, Atterberg limits, natural moisture content, bulk and dry densities, and calcium carbonate content) and 21 determinations of effective shear strength parameters (i.e., unconfined compression strength, consolidated-drained direct shear tests and consolidated-undrained triaxial tests) were carried out.

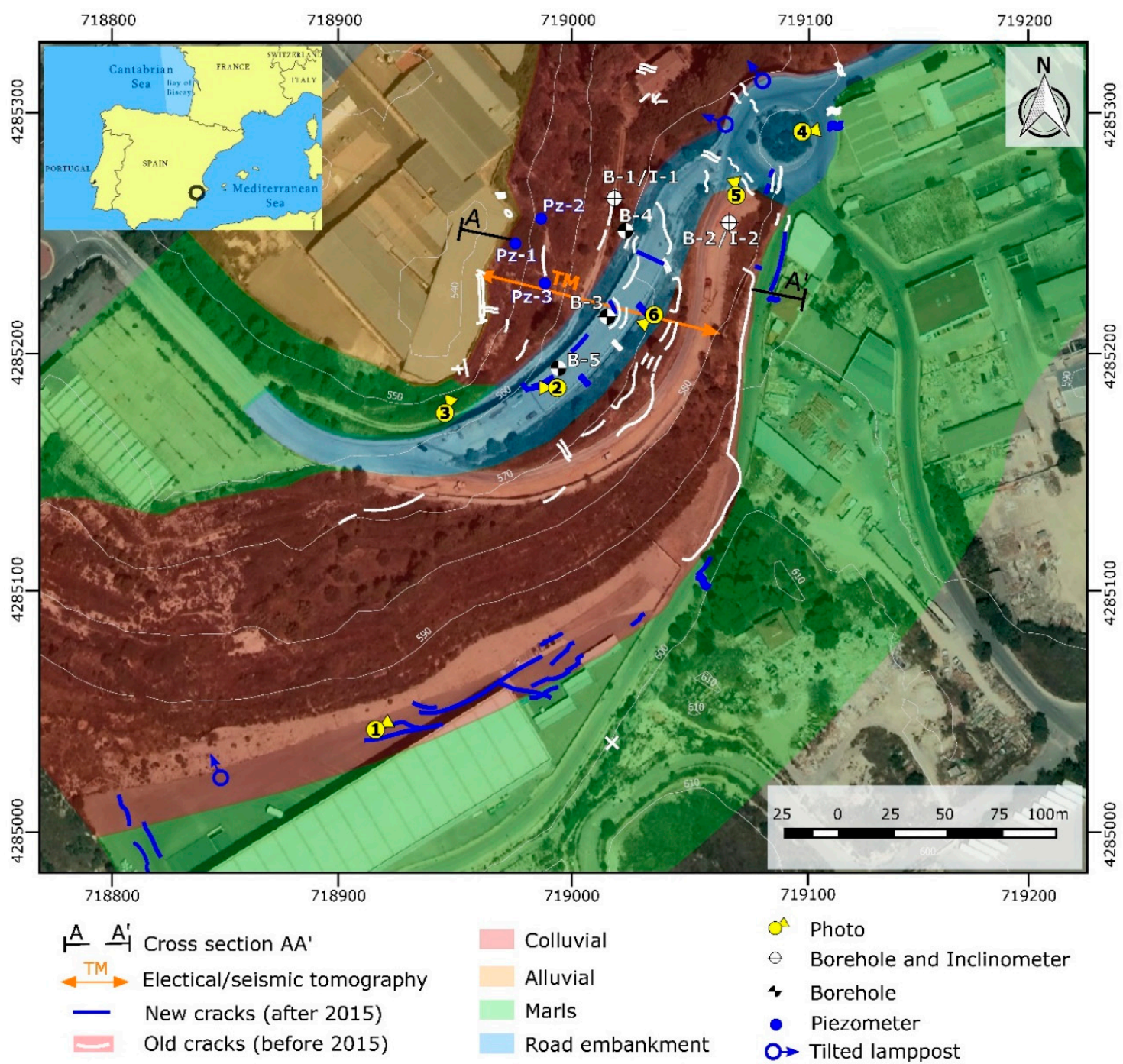

Figure 1. Location of the study site and geo-lithological sketch map and location of installed instruments. 


\subsection{Geophysics Characterization}

Two geophysical methods, electrical resistivity tomography and P-wave seismic refraction tomography, were used to study this landslide. The electrical resistivity method is based on measuring the electrical potentials between a pair of electrodes while transmitting a direct current between another pair of electrodes [37]. The system for the electrical resistivity tomography included a maximum of 80 electrodes with an electrode spacing of $2.5 \mathrm{~m}$. A Wenner-Schlumberger array profiling method was used to achieve a better sensitivity to changes in the horizontal and vertical directions. Measurements were taken along three profiles, one of them located along the landslide axis with a length of $110 \mathrm{~m}$, and the others two, orthogonal to the first one and perpendicular to the landslide axis, with a maximum length of $200 \mathrm{~m}$. The same three profiles were conducted while using P-wave seismic refraction tomography with a maximum of 40 geophones (resonance frequency $10 \mathrm{~Hz}$ ), which were spaced by $5 \mathrm{~m}$. The signals were generated with a spacing of $10 \mathrm{~m}$, except for one offset shot at each end spaced by $2.5 \mathrm{~m}$.

\subsection{Damage Assessment}

An inventory of the damage induced by the landslide was done by mapping the cracks that occurred on the soil surface, on the road pavement, on the bridge, and on other structures, such as retaining walls and buildings in the surrounding area. The location of the damage was mapped (Figure 1) and the type of damage described and recorded, as this information can be very useful in understanding the typology and the extent of the movement, as well as to delimit the area affected by the landslide.

\subsection{Monitoring}

\subsubsection{DInSAR}

Operating C-band Synthetic Aperture Radar sensors of the new generation (SENTINEL-1 satellite) have provided long historical archives of motion rates and displacement time series at large scale, with a spatial resolution of $20 \times 4 \mathrm{~m}$ and reduced revisiting time (12 days). In detail, 78 SENTINEL-1 ascending images acquired in the time-span May 2015-February 2018 and 67 SENTINEL-1 descending images acquired in the time-span August 2015-January 2018 have been processed by means of the Coherent Pixels Technique $[38,39]$ to detect surface deformations of the considered area. The analysis has been carried out by exploiting a coherent-based method for pixel selection.

The area of interest selected for the SAR analysis covers about $35 \mathrm{~km}^{2}$, encompassing the whole territory of Alcoy municipality. Only the interferograms whose image pairs had spatial and temporal baselines lower than fixed values, have been selected in order to detect pixels with high phase quality. The values fixed for spatial and temporal baselines were $100 \mathrm{~m}$ and 100 days, respectively. A total of 391 and 306 interferograms were obtained by ascending and descending processing, respectively. Furthermore, to have a sufficient number of targets covering the entire study area, and to display, at the same time, a phase standard deviation of approximately $20^{\circ}$ (which corresponds to a displacement standard deviation of $1.5 \mathrm{~mm}$ ), a threshold of coherence equal to 0.60 has been set. As a result, about 8300 targets have been selected by ascending data and 4500 persistent scatterers (PS) by descending images. However, as it is possible to note, PS localized within Alcoy urban settlement mainly correspond to man-made features, such as existing structures, roads, and retaining walls. It is worth noting that, to the subject area, the local incidence angle in flat areas is equal to the incidence angle.

\subsubsection{LiDAR}

A Leica C10 terrestrial laser scanner was used for monitoring the bridge. This scanner has an angular accuracy of 12" and a distance accuracy of $4 \mathrm{~mm}$, being the noise $2 \mathrm{~mm}$ at $50 \mathrm{~m}$ [40]. Two scans were done for change detection, in 6th May 2016 and 27th April 2018 (Figure 2). In the first campaign, three scan stations were performed at the locations that are shown in Figure 2. In the second 
campaign, three stations were performed in the same locations and an additional station was included. In both scans, the resolution was set up to high resolution $(5 \mathrm{~cm}$ at $100 \mathrm{~m})$. In the first campaign, the true colours were captured and assigned to the three-dimensional (3D) point cloud. In the second campaign, the colours were not acquired. Both 3D point clouds were registered using existing stable buildings near the bridge through the Iterative Closest Point (ICP) method that is available in the CloudCompare software. To detect the changes between those two stages, the registered 3D point clouds were compared while using the $\mathrm{M} 3 \mathrm{C} 2$ plugin of CloudCompare [41]. The analysis of the change detection results gives us information regarding the relative movements occurred between the different parts of the bridge, the abutments, and the pavement of the road near the bridge.

(a) 2016 survey

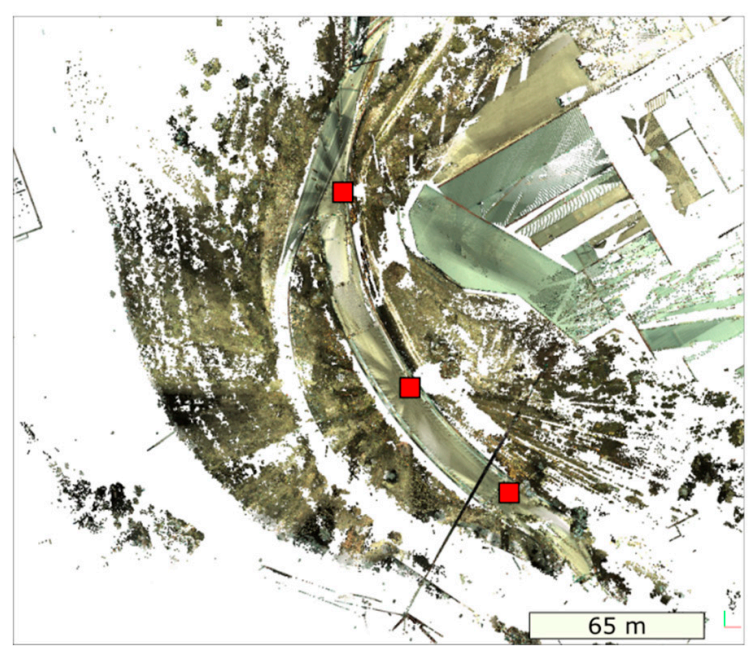

(b) 2018 survey

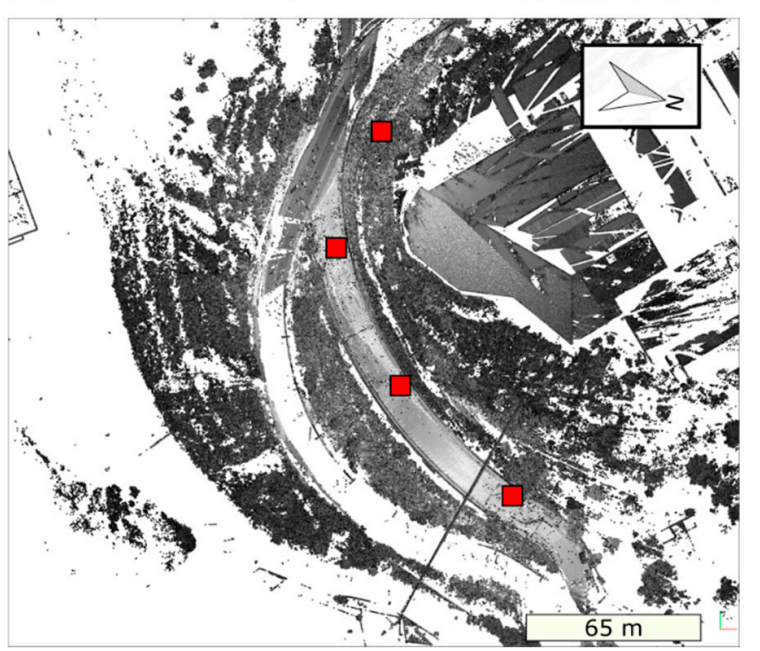

Figure 2. Top view of the two three-dimensional (3D) point clouds acquired on (a) 6th May 2016 and (b) 27th April 2018.

\subsubsection{Inclinometers}

Two vertical inclinometers were installed in boreholes I-1 and I-2 (Figure 1) to accurately determine the horizontal magnitude and direction of the relative displacements of the landslide and the depth of the surface of failure in two orthogonal directions. Inclinometers I-1 and I-2 are located in the lower and upper parts of the slope, respectively, reaching depths of 40 and $25 \mathrm{~m}$. The cumulative relative displacements in both inclinometer boreholes were measured over time by repeating the measurements approximately every month in the time span 2012-2013. The displacement error of this equipment is $\pm 2 \mathrm{~mm}$ per $25 \mathrm{~m}$ depth.

\subsubsection{Topography}

Field surveys and topographic analysis was carried out to investigate the surficial movements that occurred on the bridge superstructure and on the lateral abutments. A total station Trimble 5503 DR, with an angular and distance accuracy of 3" (1.0 mgon) and $\pm 2 \mathrm{~mm}+2 \mathrm{ppm}$, respectively, was used for this work. The field surveys were carried out twice per month from January 2015 to July 2018, determining the position of 23 control points that were located below and on the bridge, and on both abutments. The relative movements of these points were estimated taking a stable point located about $80 \mathrm{~m}$ south from the south abutment as a reference.

\subsubsection{Elastomeric Bearing Pads}

The relative movements between the precast concrete beams of the bridge and the support piers were measured from 2012 to 2018. These movements can help to understand the cause-effect relationship between the landslide kinematics and the distortions of the infrastructure. The distance 
between the centre of the bottom face of the beams and the initial position of the beams over the elastomeric bearing pads was measured with a tape-meter for all of the beams in the bridge. The tendency and magnitude of the movement can be assessed for each pier while analysing this data.

\section{Results}

\subsection{Geological and Geotechnical Survey}

Four types of soils/rocks were distinguished according to the outcrops, the results of the tests and the analysis, interpretation, and correlation of the boreholes: (1) Road embankment, mainly composed of clayey gravels and only located on the laying out of the road; (2) colluvial deposits (Quaternary) composed of clayey sands with some gravels, located on the superficial part of the slope; (3) alluvial deposits (Quaternary) composed of clayey sands with gravels, located on the toe of the slope; and, (4) marls (Tertiary) composed of clays and marls with some intercalated calcareous layers. Figure 1 displays the four soils distribution.

The geotechnical properties of the different lithological layers are summarized in Table 1, showing the mean value, the standard deviation, and the number of tests done for each geotechnical parameter determination. As it can be seen in this table, the tests were done for three of the four types of soils, being the alluvial deposits the only stratum without tests results, as it is located at the bottom of the slope. Figure 3 depicts a cross-section of the slope, where, beneath the colluvial deposits, a more superficial weathered clay layer has been distinguished within the Tertiary marls. The water table was detected at a depth of 5 and $7 \mathrm{~m}$ in boreholes-inclinometers 1 and 2, respectively, at the time of the drilling.

The groundwater level was measured in the three piezometers installed in the slope in June 2012. The groundwater level depth was only $0.5,1.3$, and $4.5 \mathrm{~m}$ b.g.l. in piezometers 1,2 , and 3 , respectively (Figures 1 and 3). As can be seen in Figure 3, the depth of the groundwater level at the toe of the slope is slightly shallower than the boundary between the colluvial deposit and the marl stratum. No information was available regarding the groundwater level at the middle and top of the slope.

A two-dimensional back analysis of the slope stability by the limit equilibrium method was performed to assess the slip surface that is depicted in Figure 3. This analysis was performed while using the limit equilibrium method. The Rocscience Slide software was used for this task. The integration of monitoring in the stability analysis was done by introducing location and depth of the slip surface and of the groundwater table, detected in both inclinometers and in the three piezometers, respectively.

\subsection{Geophysical Survey}

Three profiles were conducted for both geophysical methods, electrical resistivity tomography and P-wave seismic refraction tomography, although only the profile that was located along the landslide axis will be shown in this section.

The electrical resistivity profile shows a shallow resistive layer (resistivity between 100 to $200 \Omega \cdot \mathrm{m}$ ) with a thickness of few meters (Figure 4). This corresponds to the colluvial deposits that were composed of clayey sands with some gravels. Below this layer, a low resistivity layer (5 to $30 \Omega \cdot \mathrm{m}$ ) is detected, probably corresponding to fine soils unit with high moisture content. The depth of the top of this layer is approximately the same, where the groundwater level was detected in the piezometers, see Figure 3. Finally, a last deep layer is shown in the profile with a resistivity ranging from 40 to $300 \Omega \cdot \mathrm{m}$, which could correspond to the marls stratum. The electrical layer contacts detected in the resistivity profile (Figure 4) have been drawn as brown dashed lines in the integrated cross-section depicted in Figure 3. Although the resistivity profile is not exactly in the same position as the integrated cross-section, see Figure 1, some interesting results can be observed when joining this information. Both electrical contacts seem to correspond with the contact layers between the soft soils and weathered clays and between the weathered clays and marls. The lowest contact could also correspond to the groundwater table depth as a low resistivity layer was detected. This contact depth is similar to the groundwater level depth that was observed at the piezometers, although a difference in depth is observed, which is 
probably due to the different location of the cross-section and the electrical resistivity profile and/or that the period when the geophysics and the borehole were done was different. This difference in depth between the resistivity profile and the cross-section is also observed for the depth of the layers.

Table 1. Geotechnical properties of soils. Mean value, standard deviation, and in parentheses the number of tests done.

\begin{tabular}{|c|c|c|c|c|c|c|c|}
\hline & \multicolumn{3}{|c|}{ Particle Size } & \multicolumn{3}{|c|}{ Atterberg Limits } & \multirow{2}{*}{$\% \mathbf{w}$} \\
\hline & $\%$ Gravel & $\%$ Sand & $\%$ Fines & L.L. & P.L. & P.I. & \\
\hline $\begin{array}{l}\text { Road embankment } \\
\text { (Clayey gravels) }\end{array}$ & $\begin{array}{l}39.0 \pm 5.1 \\
(4)\end{array}$ & $\begin{array}{l}25.1 \pm 4.6 \\
\quad(4)\end{array}$ & $\begin{array}{l}36.0 \pm 9.0 \\
(4)\end{array}$ & $\begin{array}{c}31.4 \pm 2.3 \\
(4)\end{array}$ & $\begin{array}{l}13.4 \pm 1.1 \\
(4)\end{array}$ & $\begin{array}{c}18.0 \pm 1.6 \\
(4)\end{array}$ & - \\
\hline $\begin{array}{c}\text { Quaternary } \\
\text { Colluvial deposits } \\
\text { (Clayey sands with } \\
\text { some gravels) }\end{array}$ & $\begin{array}{c}1.0 \pm 2.0 \\
(4)\end{array}$ & $\begin{array}{l}52.7 \pm 17.8 \\
\quad(4)\end{array}$ & $\begin{array}{l}46.4 \pm 19.7 \\
(4)\end{array}$ & $\begin{array}{c}33.6 \pm 3.8 \\
(4)\end{array}$ & $\begin{array}{l}18.5 \pm 3.2 \\
(4)\end{array}$ & $\begin{array}{l}15.1 \pm 3.1 \\
\quad(4)\end{array}$ & $\begin{array}{c}17.6 \pm 3.7 \\
(4)\end{array}$ \\
\hline \multirow[t]{2}{*}{$\begin{array}{c}\text { Tertiary } \\
\text { (clays and marls) }\end{array}$} & $\begin{array}{c}3.2 \pm 9.5 \\
(34)\end{array}$ & $\begin{array}{l}21.9 \pm 9.3 \\
(34)\end{array}$ & $\begin{array}{c}74.9 \pm 22.3 \\
(34)\end{array}$ & $\begin{array}{l}44.2 \pm 9.8 \\
\quad(34)\end{array}$ & $\begin{array}{c}21.1 \pm 3.1 \\
\quad(34)\end{array}$ & $\begin{array}{l}23.1 \pm 8.5 \\
\quad(34)\end{array}$ & $\begin{array}{c}22.6 \pm 3.9 \\
(32)\end{array}$ \\
\hline & $\begin{array}{c}\text { Bulk } \\
\text { density } \\
\left(\mathrm{kN} / \mathrm{m}^{3}\right)\end{array}$ & $\begin{array}{c}\text { Dry } \\
\text { density } \\
\left(\mathbf{k N} / \mathrm{m}^{3}\right)\end{array}$ & $\mathrm{q}_{\mathrm{u}}(\mathrm{kPa})$ & $\mathrm{c}^{\prime}(\mathrm{kPa})$ & $\sigma^{\prime}\left({ }^{\circ}\right)$ & $\begin{array}{c}\mathrm{MCO}_{3} \\
(\%)\end{array}$ & Nspt \\
\hline $\begin{array}{l}\text { Road fillings } \\
\text { (Clayey gravels) }\end{array}$ & - & - & - & - & - & - & $\begin{array}{c}25.0 \pm 21.1 \\
\text { (3) }\end{array}$ \\
\hline $\begin{array}{c}\text { Quaternary } \\
\text { Colluvial deposits } \\
\text { (Clayey sands with } \\
\text { some gravels) }\end{array}$ & $\begin{array}{l}20.5 \pm 1.0 \\
\quad(4)\end{array}$ & $\begin{array}{l}17.5 \pm \\
1.4(4)\end{array}$ & - & $22 \pm 31(2)$ & $\begin{array}{c}36.5 \pm \\
10.6(2)\end{array}$ & - & - \\
\hline $\begin{array}{c}\text { Tertiary } \\
\text { (clays and marls) }\end{array}$ & $\begin{array}{l}20.0 \pm 0.7 \\
\quad(22)\end{array}$ & $\begin{array}{l}16.3 \pm 0.8 \\
\quad(22)\end{array}$ & $\begin{array}{c}329 \pm 213 \\
(15)\end{array}$ & $\begin{array}{l}44 \pm 31 \\
(19)\end{array}$ & $\begin{array}{l}29,6 \pm 7.3 \\
\quad(19)\end{array}$ & $\begin{array}{l}57.0 \pm 4.6 \\
\quad(7)\end{array}$ & $\begin{array}{c}28.0 \pm 12.7 \\
\text { (9) }\end{array}$ \\
\hline
\end{tabular}

L.L.: Liquid Limit; P.L.: Plastic Limit; P.I.: Plasticity Index; w: moisture content; $q_{u}$ : Unconfined Compressive Strength; $c^{\prime}$ : effective cohesion; $\varnothing^{\prime}$ : effective angle of internal friction; Nspt: Standard Penetration Test blow count.

A

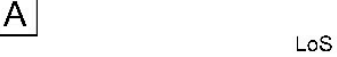

Los
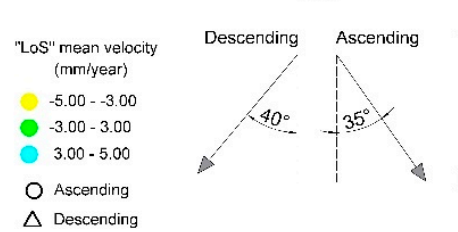

Pz Piezometer

-- Electrical layer contact
-- Seismic refractor

inclinometer 2

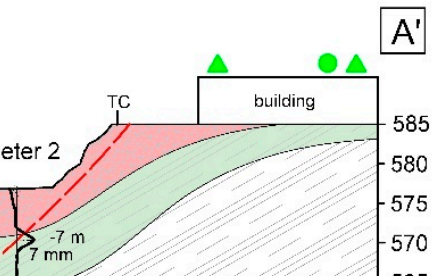

$\triangle$ Descending

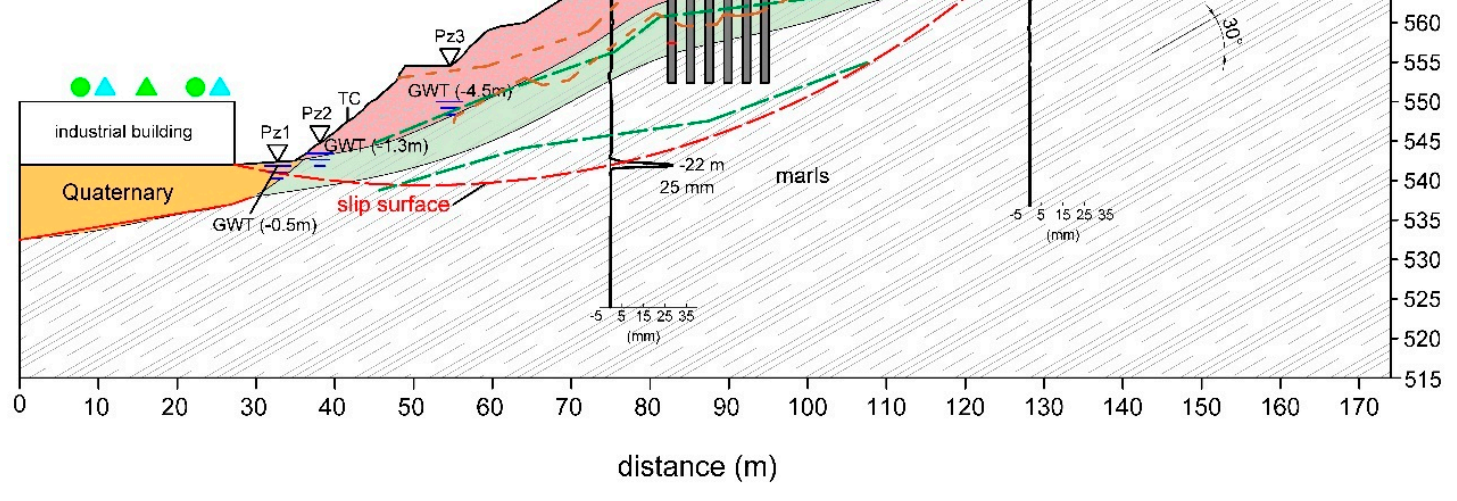

Figure 3. Integrated Cross-section $A-A^{\prime}$ of the slope where Differential Interferometry Synthetic Aperture Radar (DinSAR) information, inclinometers and the potential slip surface have been included. Note that the plotted displacements correspond to the time period November 2012 to February 2013. 
Figure 5 shows the seismic tomography profile along the landslide axis. From this figure, three distinct layers can be distinguished with P-wave velocities increasing with depth. A relatively thin surficial layer with low velocity (less than $1000 \mathrm{~m} / \mathrm{s}$ ) can be observed in this figure. This seismic layer corresponds to the colluvial deposits. A second seismic layer is distinguished below the first one with a P-wave velocity between 1000 and $2000 \mathrm{~m} / \mathrm{s}$. Lastly, a bedrock layer with a P-wave velocity higher than $2500 \mathrm{~m} / \mathrm{s}$ is distinguished in greater depth. These three seismic layers correspond to the stratum of clays and marls. The lower seismic velocity that was measured in the top stratum is because the top stratum is superficially weathered. The refracting interfaces that were observed at the seismic tomography profile (Figure 5) have been drawn as green dashed lines in the integrated cross-section that is depicted in Figure 3. As for the resistivity profile, the tomography profile is not exactly in the same position as the integrated cross-section, see Figure 1, but some interesting results can also be seen when joining this information. While the highest seismic refractor seems to be a contact layer, the lowest one could correspond to the slip surface, as it is nearly at the same depth as the observed in the inclinometer 1 and is very similar to the slip surface, as assessed by the slope stability analysis (red dashed line).

\subsection{Damage Assessment}

The damage inventory that developed during the field campaigns and the location of the crack is shown in Figure 1. A remarkable long tension crack, over $100 \mathrm{~m}$, was observed on the top of the slope, not just located above the bridge, but also spreading towards the southwest. This tension crack affects the outside pavement of the industrial building located south from the bridge on the top of the slope (Figures 3 and 6-1). It is also noteworthy the number of tension cracks on the soil surface some meters above the bridge and below the structure (Figure 6-2). However, fewer cracks were observed at the toe of the slope, although the retaining wall of one of the industrial buildings is clearly cracked and tilted (Figure 6-3). Tension cracks have also been clearly detected north of the bridge, in the concrete fence of some plots and by the roundabout pavement (Figure 6-4,5).

Damage has also been observed on the bridge structure. The level of damage is so severe that some precast beams that were placed on the supporting piers have been displaced out from its elastomeric bearing pads, breaking some exterior shear keys (Figure 6-6). The broken exterior shear keys are those located in the east part of the bridge, the top slope side of the bridge.

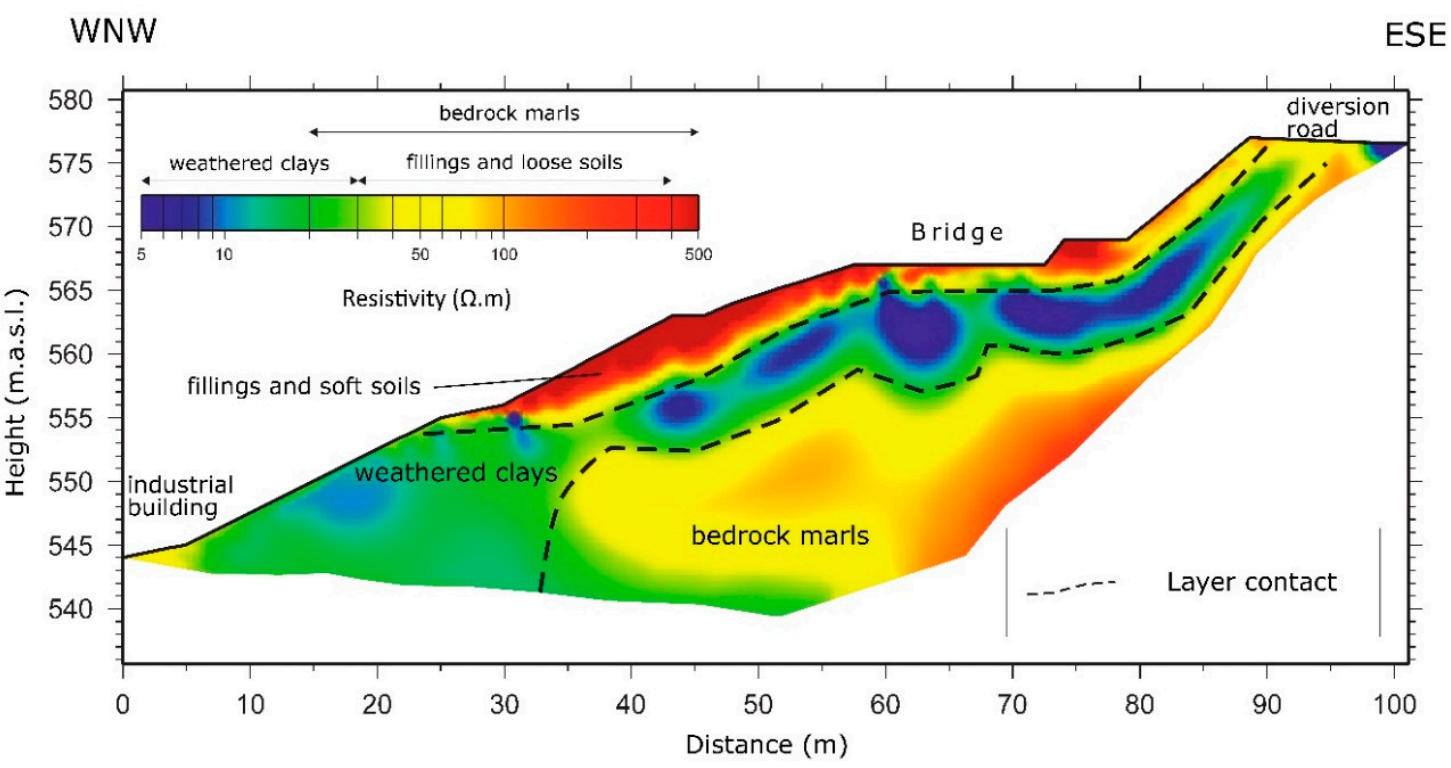

Figure 4. Electrical Resistivity Tomography (ERT) oriented mostly perpendicular to the slope (TM in Figure 1. Three types of soils have been identified according to their resistivity. The black dashed lines show the contact between these soils. 


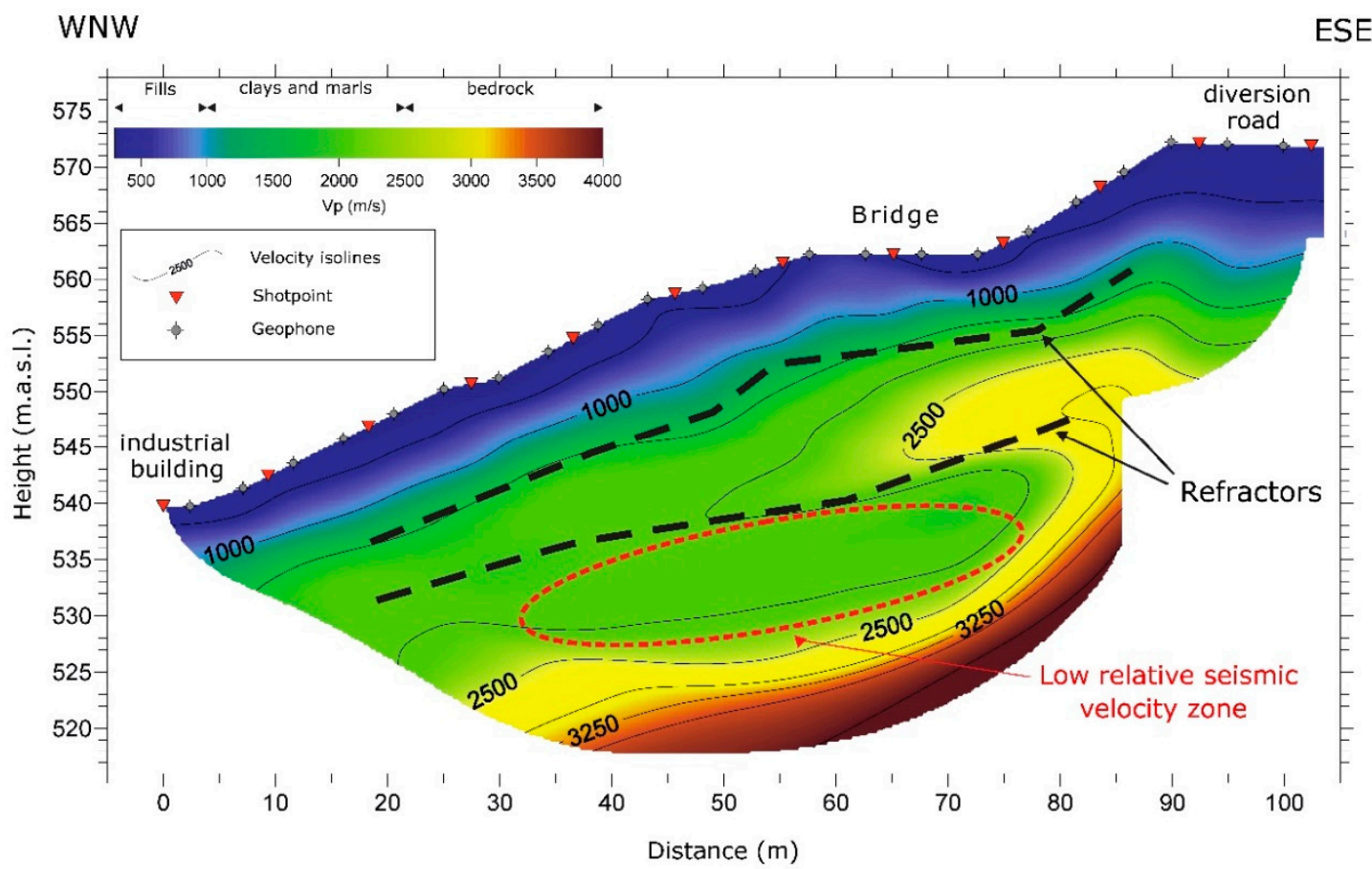

Figure 5. Seismic tomography oriented mostly perpendicular to the slope (TM in Figure 1). The black dashed lines show the refractors within the soil body.

\subsection{Monitoring}

\subsubsection{DInSAR}

It is well known that the DInSAR technique is insensitive to N-S displacements. Additionally, significant topographic variations can cause distortions in the SAR images (i.e., foreshortening and layover) and to obscure areas from view (i.e., shadowing). Therefore, these limitations have been evaluated while using the R-index [42] and the percentage of the real movement [43] in the nearby area of the monitored bridge. The results that were obtained for both indexes suggest that the bridge area presents high visibility for the descending track (R-index higher than 0.4 ) and a good percentage of the detectable deformation (higher than $40 \%$ ) and, therefore, PS detection mainly depends on land use. Despite that, only some PS give us information regarding the displacements' pattern of the bridge and the nearby built areas. The results of the DInSAR analysis are shown in Figure 7. The stability range is coloured in green and it represents a velocity of $\pm 3.0 \mathrm{~mm} /$ year. Unfortunately, most of the PS are located in built areas and few PS are on the bridge and in the vicinity areas. One of these points is PS-1, located at the top of the slope and showing a Line of Sight (LoS) movement with a velocity of $-7,43 \mathrm{~mm} /$ year. Nevertheless, the velocity of other points located inward the top of the slope is within the stability range. This may mean that the top boundary of the slide is a few meters from the edge of the slope. PS-2 is within the stability range and this could mean that it is outside the east boundary of the slope, as other points located further east do not show any movement. Other interesting points are those that are located at the toe of the slope, for example, PS-3 and PS-4. These points show an upward velocity of $3.02 \mathrm{~mm} / \mathrm{year}$, which could mean that a rotational slide is affecting the slope, moving down the points that are located at the zone of depletion and upward those points that are located at the zone of accumulation. This information can be seen at the displacement time series in Figure 8. In this figure, it is depicted the rainfall data corresponding to the same time-span of the satellite acquisition, every 12 days, and the cumulative displacement of the points (red and blue lines for ascending and descending tracks, respectively). It can be seen as the velocity of these points increased after the rainfall period starting at the end of 2016 for the descending and ascending tracks. 

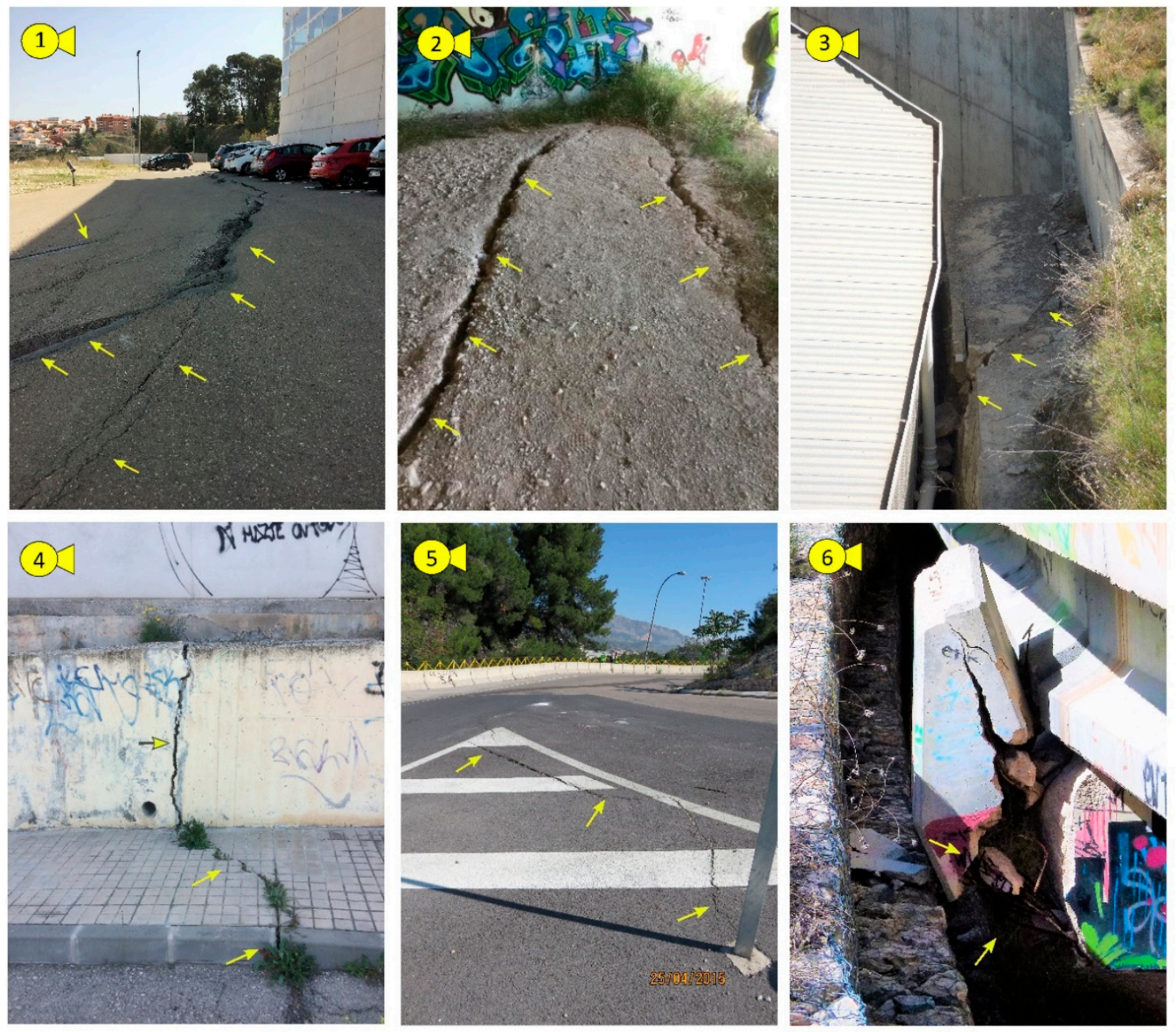

Figure 6. Photography of damages. (1) Crack at the head of the slope. (2) Crack on the soil surface beneath the bridge. (3) Broken wall at the bottom of the slope. (4) Cracked concrete fence located north of the bridge. (5) Crack on the pavement at the roundabout, north of the bridge and tilting of the lamppost. (6) Shear key broken because of precast beam lateral movement. Photos location are shown in Figure 1.

\subsubsection{Lidar}

Figure 9 shows the results of the relative $\mathrm{M} 3 \mathrm{C} 2$ normal distance between the two scans that were carried out in May 2016 and April 2018. For each estimated distance the M3C2 method computes the distance uncertainty. The uncertainty presents a mean value of $5.685 \mathrm{~mm}$, being the standard deviation of $11.975 \mathrm{~mm}$ (the closer to zero the better) [41,44]. Figure 9 suggests a relative downward movement of the north abutment and of the bridge deck. Nevertheless, the south abutment can be considered to be stable. The downward movements that were detected are approximately 3 and $2 \mathrm{~cm}$ for the north abutment and the top of the deck, respectively. Two cross-sections of the bridge are shown in Figure $9 \mathrm{~b}, \mathrm{c}$. Figure $9 \mathrm{~b}$ depicts the relative displacement of the point $\mathrm{P}$. This point corresponds to the location of the upper corner of the kerb in May 2016, whilst point $\mathrm{P}^{\prime}$ corresponds to the location of the same point in April 2018. As can be seen in this figure, the relative horizontal displacement of this point is equal to $6.5 \mathrm{~cm}$ and it moves towards the outer part of the slope. Regarding the vertical displacement, point $P$ has a descending movement that is equal to $3.1 \mathrm{~cm}$. The uplifts (red area in Figure $9 \mathrm{a}$ ) that are located on the west part of the processed area are due to the resurfacing of the diversion road. 


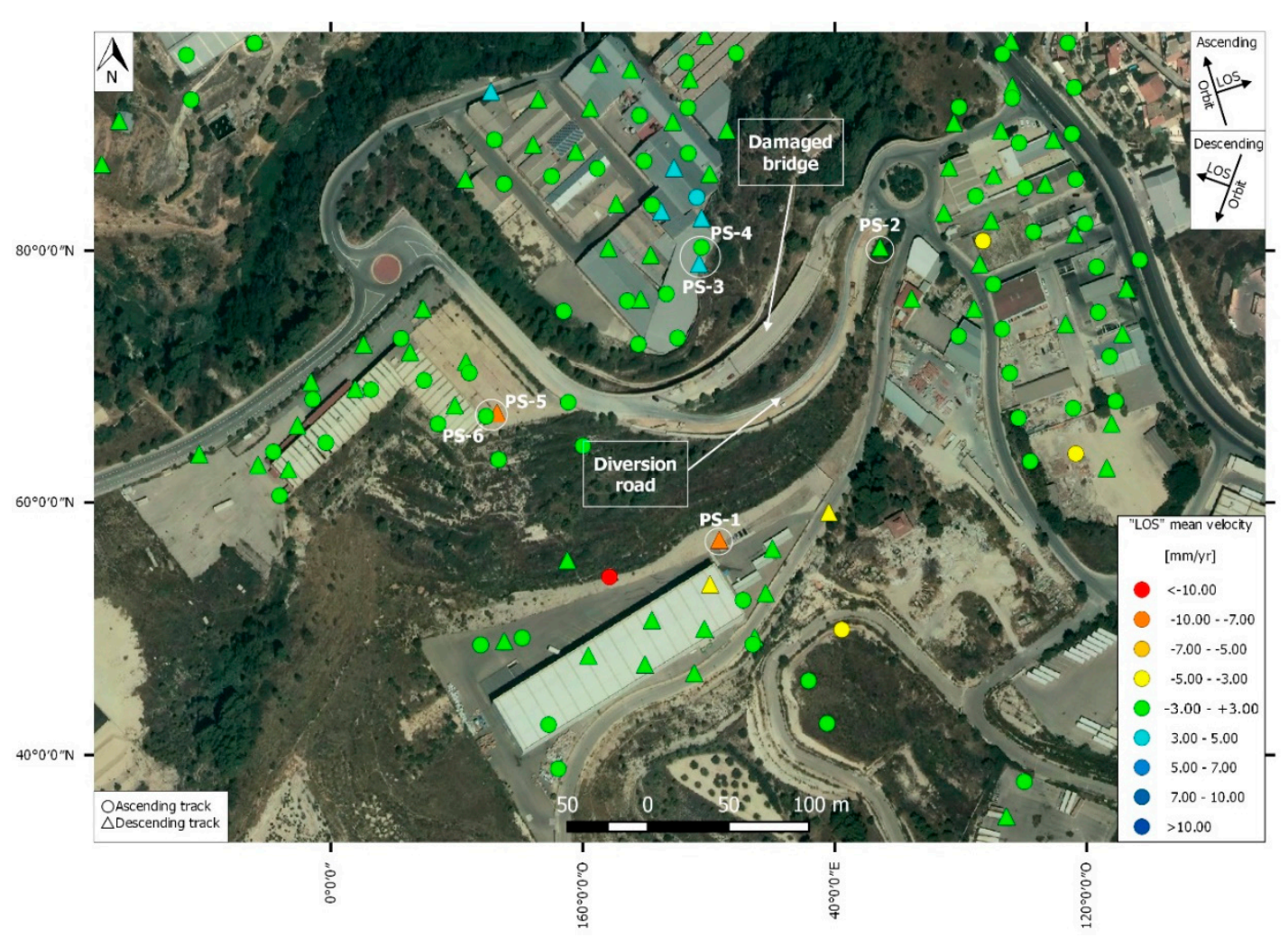

Figure 7. Results of DInSAR analysis. Mean displacement velocity recorded by ascending (circle) and descending (triangle) tracks.

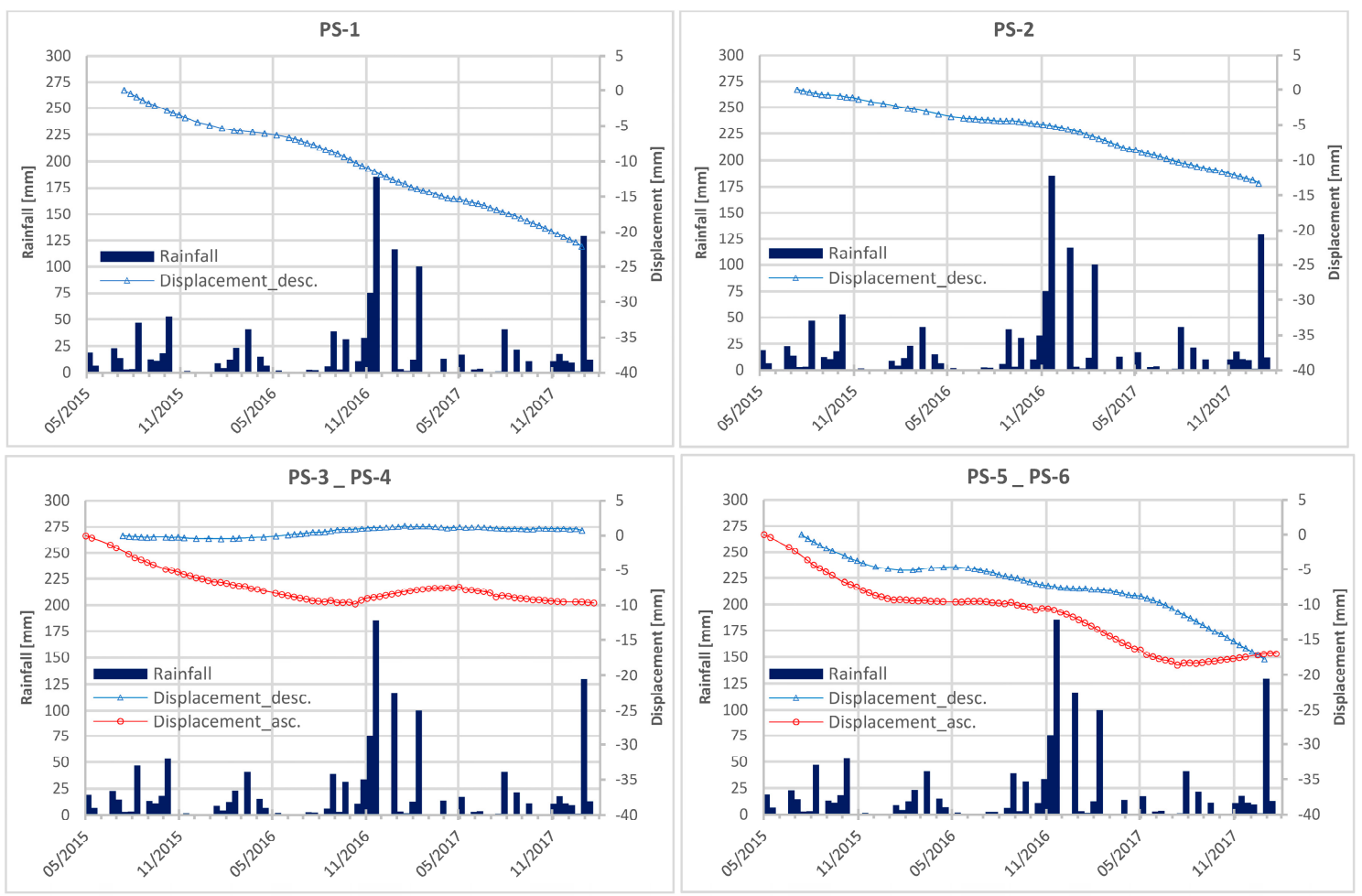

Figure 8. Time series of displacement of points located at the head (PS-1), bottom (PS-3 and PS-4), eastward (PS-2) and westward (PS-5 and PS-6) of the slope, see Figure 7. The displacements are measured along the LoS. 
(a) $\mathrm{M} 3 \mathrm{C} 2$ distance (normal) $[\mathrm{m}]$

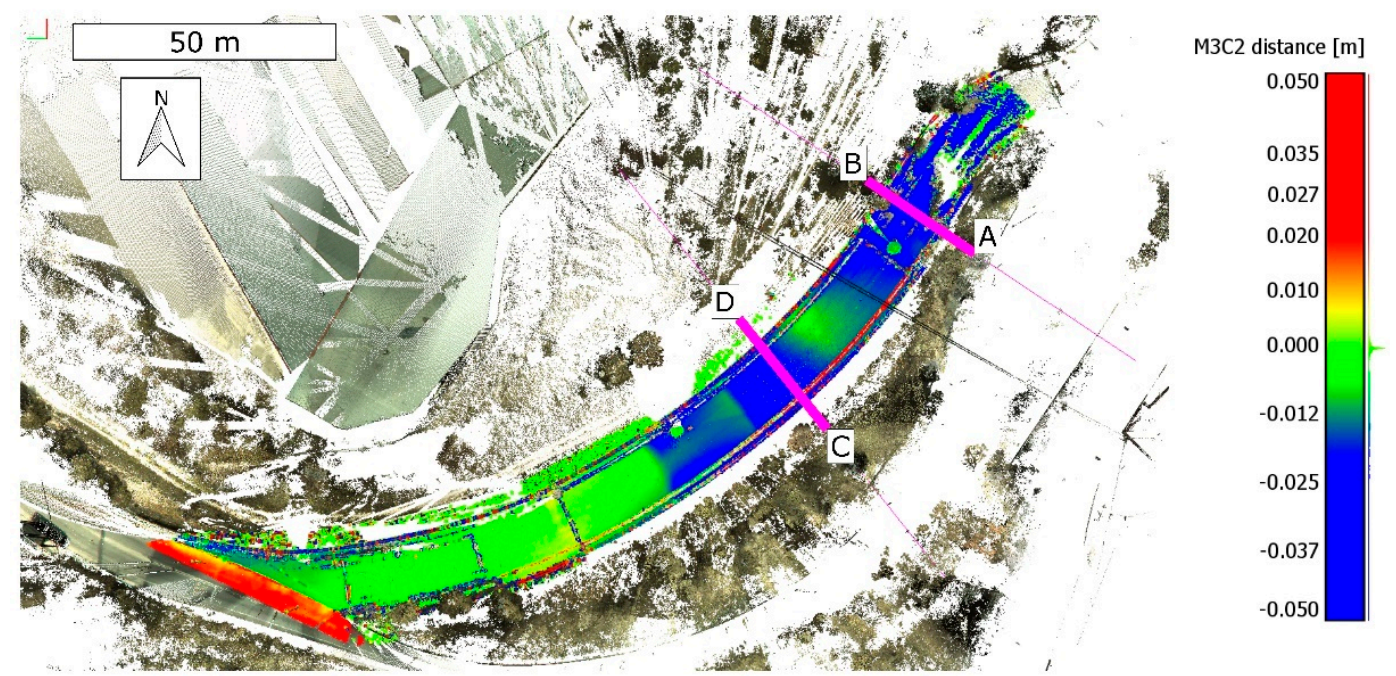

(b) Transect A-B $[\mathrm{m}]$

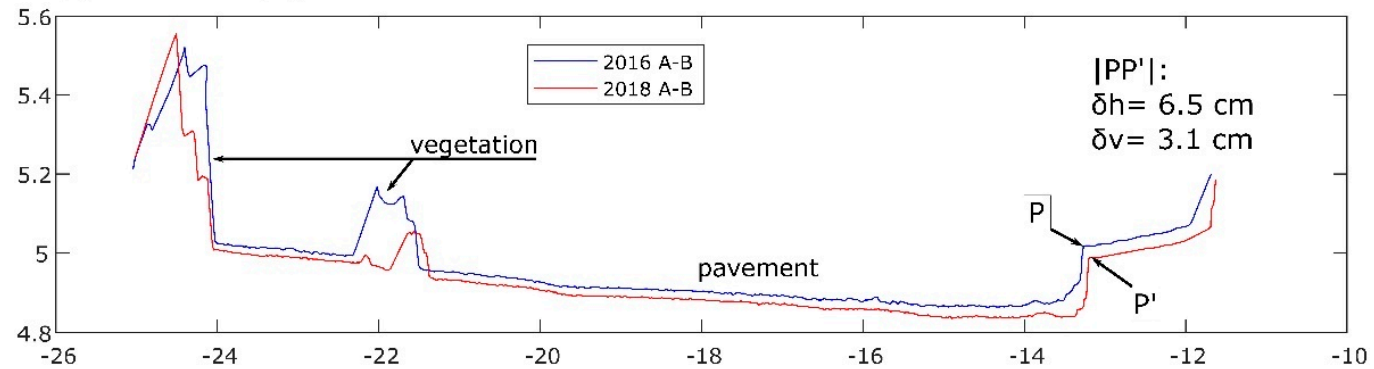

(c) Transect C-D [m]

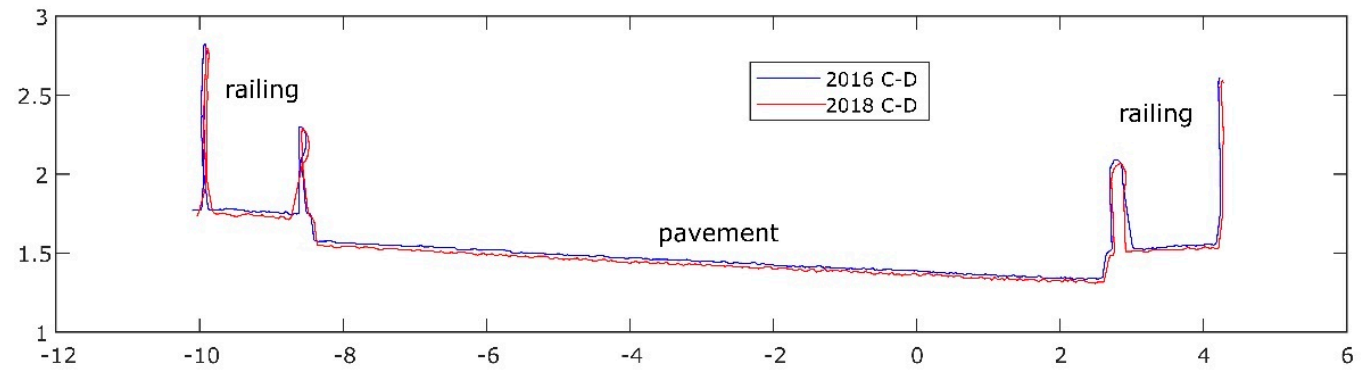

Figure 9. (a) Comparison of LiDAR models between May 2016 and April 2018 and location of the extracted steepest slope transects; (b,c) transects of the 3D point cloud of stages 2016 and 2018.

\subsubsection{Inclinometers}

The inclinometer data are shown in Figure 3, where a sliding failure surface located at a depth of 22 $\mathrm{m}$ in the inclinometer 1 and of $7 \mathrm{~m}$ in the inclinometer 2 is depicted. The rate of displacement is different for both inclinometers. The maximum shear displacement that was recorded in the inclinometer 1 was near $50 \mathrm{~mm}$ (on the slope surface) in less than three months with a mean rate of displacements of about $20 \mathrm{~mm}$ per month. The inclinometer 2 showed a maximum shear displacement of less than $10 \mathrm{~mm}$. Both inclinometers were installed in November 2012, being the casing of the inclinometer 1 broken in February 2013 due to the shear deformation that was caused by the landslide.

\subsubsection{Topography Survey}

Twenty-three points that were analysed by means of a total station have been sorted in four groups according to its location: (a) north abutment, (b) on the bridge pavement, (c) below the bridge 
(upper side of the cap piles), and (d) south abutment. As can be seen in Figure 10, the control points were checked from January 2015 to July 2018. Although the time-series are quite noisy, the south abutment presents the lowest total horizontal displacement, while the north abutment and the points located below the bridge show the highest displacement. A differential movement is observed between the points that are located below and on the bridge, being those below the bridge, which present higher displacements. Looking at Figure 10 seems that human errors such as inconsistent setup could have considerably reduced the accuracy of the survey. For this monitoring proceedings such as redundancy of observations could have reduced the possibility of blunders [45]. Despite that, the trend of the different areas' movements can be seen in the figure while looking at the general trends of the displacements throughout the sigmoidal regression lines of these four groups. North abutment points and points that are below the bridge have similar movements and trends. Nevertheless, the points on the south abutment show a totally different trend and displacements. The points that are located on the bridge pavement show a similar trend to those that are located on the north abutment and below the structure, although the points located on the pavement show smaller displacements than those that are located below the structure. It is worth highlighting that the only purpose of these regression lines is to show the general trends of the four areas, not the prediction of displacements.

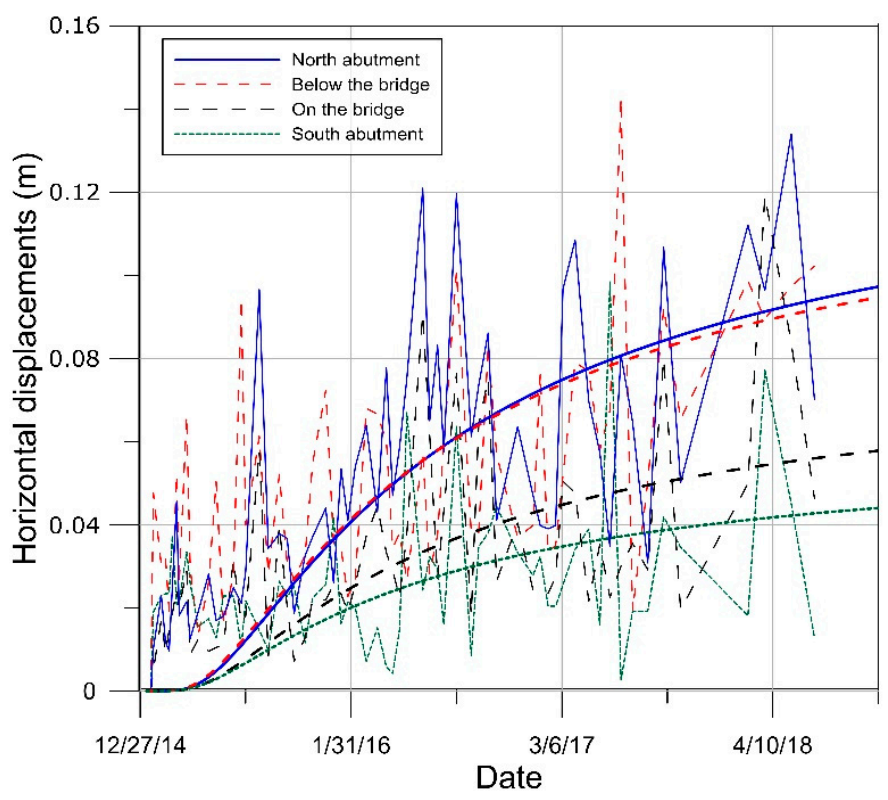

Figure 10. Average horizontal displacements evolution of the control points sorted by its location: (a) north abutment, (b) On the bridge pavement, (c) below the bridge (upper side of the cap piles), and (d) south abutment.

Regarding the vertical displacements, the points on the north abutment have a downward average movement of $5.0 \mathrm{~cm}$ in the time span from January 2015 to July 2018, whilst the average descending movements of the points on the bridge deck is equal to $3.4 \mathrm{~cm}$. These movements are consistent with those that were obtained with Lidar technique from May 2016 to April 2018 where 3.1 and $2.0 \mathrm{~cm}$ downward movements were measured for points on the north abutment and on the bridge deck, respectively.

\subsubsection{Elastomeric Bearing Pads}

The relative movement between the precast concrete beams and the support piers have been measured for six years, from 2012 to 2018. The mean displacement of the beams that were supported by each pier has been assessed. Figure 11 shows the magnitude and the direction of the relative displacements of the precast concrete beams as well as the position of the piers. The mean values of 
the total displacements during this period are 17.2, 23.7, and $30.3 \mathrm{~cm}$ for piers 1, 2, and 3 (Figure 11), respectively. The mean rates of displacements are 2.9, 3.9, and $5.1 \mathrm{~cm} /$ year for piers P1, P2, and P3, respectively.

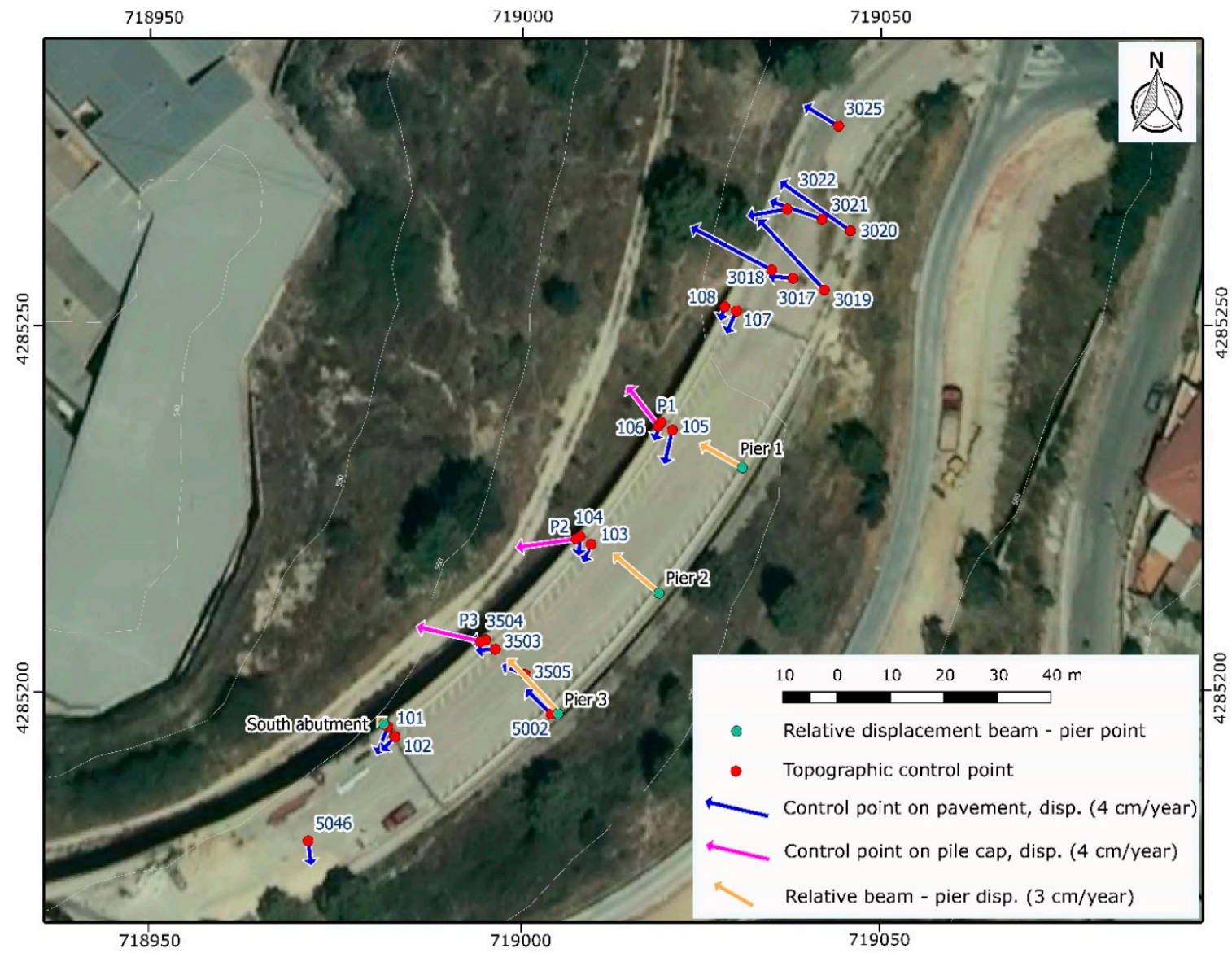

Figure 11. Horizontal displacements of the control points measured by topographic surveys and relative displacements between the precast concrete beams and the supporting piers. All the topographic control points are located on the road pavement, except for P1, P2 and P3 which are on the pile cap surface below the bridge.

\section{Discussion}

The integration of multiple sources of information allowed for determining the depth, mechanism of failure, and boundaries of the landslide. By means of the geotechnical investigation, three types of soil/rock were found to be involved by the landslide, colluvial deposits, composed of clayey sands with some gravels and located on the superficial part of the slope, and clays and marls with some intercalated calcareous layers. The spatial distribution of these three types of soil was defined by the boreholes and geophysical techniques. It was detected that the superficial layer of the colluvial deposits has an approximately constant thickness of a few meters. Furthermore, the marl stratum is below the colluvial and it presents a lower seismic velocity in the upper part, probably because the stratum is superficially weathered.

Some limitations of the geophysical survey, such as not providing direct information regarding the terrain, can be overcome by the integration with data from other sources. In this sense, joining the geophysics data into the integrated cross-section, electrical layers seem to match with the geological-geotechnical layers detected by the boreholes. Regarding the seismic information, the lowest refractor observed in the seismic profile seems to match the slip surface observed in the inclinometer 1 and the slip surface assessed by the slope stability analysis. This velocity contrast that is induced 
between the stable bedrock and the unstable mass due to the internal strain affecting the landslide was observed by other researchers [13,46].

The damage assessment inventory contributes to defining the extension of the affected area. A long crack was observed on the top of the slope, which affects the pavement of the street and the pavement of the industrial building. This crack could correspond to the east boundary of the landslide (i.e., the crown crack); this is confirmed by the DInSAR analysis, as the points located on the edge of the slope present a downward movement whilst those points located a few meters from the edge do not show any significant activity. The west boundary of the landslide corresponds to the toe of the slope as only the retaining wall at the base of the slope and the points near this wall present some damage. Additionally, looking at the DInSAR results, Figure 7, the points located at the toe of the slope present an upward movement, while those located east from the bridge and further from the toe do not show any significant movement. The sense of the movement detected by the DInSAR analysis, downward for the points at the top and upward for those points at the base, suggests that a rotational slide is affecting the slope. This mechanism matches the information provided by the inclinometers, Figure 3, where it can be seen that a rotational landslide fits with the depth of the sliding surface location at both inclinometers. From the dip and the dip direction of the stratum (Figure 3), a combined landslide mechanism is also possible, i.e., a roto-translational slide. According to the crack mapping, the northern boundary of the landslide seems to be located by the roundabout. There is not any PS on the roundabout, but the PS that is located east from this infrastructure is within the stability range.

Furthermore, the topography control points that are located on the north abutment show horizontal displacements similar to those points located below the bridge. Also, similar trends in the control points movement on the north abutment and below the bridge are observed, Figure 10. In spite of the accuracy of the survey seems to have been reduced by procedure and human errors, as it seems to be due to the noise that can be seen at the time-series (Figure 10), the general trends detected by the topography survey match with the information collected from other techniques, such as DInSAR or damage assessment, where this information is redundant. These results are also confirmed by the LiDAR measured movements, Figure 9, where the normal displacements of the north abutment and the bridge deck are higher than those measured on the south abutment where the points showed a stable behaviour. Therefore, the north abutment is probably within the landslide contour. Regarding the south boundary, the cracks that are located most southern are those placed below the bridge, between the south abutment and the pier 3, Figure 6-2. The lack of PS at important locations has been the main drawback observed in the present study for the DInSAR technique. In this sense, for example, there is no DInSAR information close to the south abutment, but the closest PS about $75 \mathrm{~m}$ south from the abutment is within the stability range. Considering the topography survey, the control points located on the south abutment show lower horizontal displacements compared to those points placed below the bridge (Figure 10). The general trends of the displacements between the points that are located below the bridge and on south abutment are also very different. Moreover, the Lidar points located on the south abutment did not show a significant movement. Therefore, the south abutment is probably out of the main landslide affecting the bridge.

When looking at the horizontal displacements of the points that were located on the bridge pavement, Figure 10, an intermediate value between the horizontal displacements of the points located below the bridge and those on the south abutment is observed. The general trend of the points located on the pavement of the bridge is similar to that observed on the points below the bridge, although the points located on the pavement show a dampened movement when compared to those located below the structure. This difference in the rate of the horizontal displacement between the bridge, the ground below the bridge and the south abutment is also confirmed by the movement of the precast beams placed on the supporting piers. The precast concrete beams of pier 3 (the closest to the south abutment) show a relative displacement eastward, the opposite direction to the landslide movement, as compared to the pier and its foundation. This relative displacement between beams and piers is also shown for piers 2 and 1, although it is gradually decreasing as we move away from the south abutment (i.e., from 
pier 1 to pier 3). This can confirm that the south abutment is outside the main movement affecting the landslide. The beams over the elastomeric bearing pads in the south abutment only show a small relative movement towards the west, the same direction as the landslide. However, the beams on the closest pier to the south abutment show the highest relative displacement, in this case towards the east, which is the opposite direction to the landslide movement. This could be because the beams are attached to the deck of the bridge and the deck is connected to the south abutment whose movement is smaller than the foundation movement. In the same way, the results that were provided by the LiDAR technique show a relative downward movement between the south abutment and the bridge deck compatible with this deformation mechanism of the structure. Similar results have been obtained from the vertical movement of the topography control points where the points that are located on the south abutment pavement show a smaller downward movement than those placed on the bridge pavement.

In this work, LiDAR only provided information regarding the movements of the pavement and other road elements. This is because the slope is covered by vegetation, so changes in these areas cannot be attributed to slope instability. Despite this, LiDAR, together with other techniques, allowed defining the superficial boundaries of the slide in the bridge area. LiDAR technique has also been successfully used for this purpose in previous research $[19,20]$. In the present research, the use of LiDAR and topography surveys provided additional information. Therefore, as it was stated by Barbarella and Fiani [19], it is important to carry out both types of surveys, since the data that can be acquired from each instrument are complementary. Nevertheless, contrary that what was observed by Barbarella and Fianni [19], the accuracy of the LiDAR results in the present research was higher than those that were obtained by topography surveys due to some kind of procedure error as explained above.

As it has been stated above, each of the techniques employed has been useful to understand the geometry, kinematics, and extension of the landslide, obtaining complementary information from each technique. Table 2 summarizes the contribution to the comprehensive investigation of the landslide by each technique.

Table 2. Contribution to the understanding of the landslide by the different techniques employed.

\begin{tabular}{|c|c|c|c|c|c|c|c|}
\hline & $\begin{array}{l}\text { Geology and } \\
\text { Geotechnics }\end{array}$ & Geophysics & $\begin{array}{c}\text { Damage } \\
\text { Assessment }\end{array}$ & DinSAR & LiDAR & Inclinometers & $\begin{array}{c}\text { Topography } \\
\text { Control }\end{array}$ \\
\hline $\begin{array}{l}\text { Type of soil/rock } \\
\text { involved }\end{array}$ & $x$ & & & & & & \\
\hline $\begin{array}{l}\text { Landslide } \\
\text { mechanism }\end{array}$ & $x$ & $x$ & $x$ & $x$ & $x$ & $x$ & \\
\hline $\begin{array}{l}\text { Depth of the } \\
\text { sliding surface }\end{array}$ & $x$ & $x$ & & & & $x$ & \\
\hline $\begin{array}{l}\text { Boundaries of } \\
\text { the landslide }\end{array}$ & & & $x$ & $x$ & $x$ & & $x$ \\
\hline Kinematics & & & $x$ & $x$ & $x$ & $x$ & $x$ \\
\hline
\end{tabular}

The elastomeric bearing pads monitoring has been included in the damage assessment category.

\section{Conclusions}

The combined use of multi-source information has enabled performing a comprehensive investigation of a deep-seated landslide in Alcoy, Spain. Firstly, geological and geotechnical information has been compiled through conventional borehole drilling, laboratory testing, and inclinometric measurements. This information is of paramount importance in determining the type of soil/rock involved in the landslide, its properties and the possible failure mechanism. Geophysics lets to know the spatial distribution of the soils and approximately the depth of the sliding plane. This information has been confirmed and accurately measured at some points by the inclinometers that were installed in two of the boreholes. Moreover, the lowest refractor that was observed in the seismic profile seems to match the slip surface assessed by the slope stability analysis. 
Damage mapping, DInSAR, and LiDAR information, jointly with surveying monitoring and structural damage assessment were essential for knowing the superficial boundaries of the landslide. These techniques have also provided useful information regarding the kinematics of the landslide. All of this information shows a rotational landslide that is approximately perpendicular to the slope, although with a slightly south component, which affects the colluvial stratum, clays, and marls. The north boundary of the landslide is between the roundabout and the bridge, being the north abutment within the main landslide body. Nevertheless, the south boundary is between pier 3 and the south abutment, being this abutment outside the main landslide body.

The successful case study that was illustrated in this work highlights the potential and the need for integrating multi-source data (i.e., remote sensing data and ground information) for the optimal management of complexes landslides and effective design of remedial measurements.

Author Contributions: Conceptualization R.T. and J.L.P.; methodology J.L.P., R.T., M.C. and A.R.; investigation J.L.P., R.T., M.C., A.R. and L.L., InSAR data processing L.L. and D.D.M.; processing of LiDAR datasets A.R.; writing original draft preparation J.L.P.; writing—review and editing, all.

Funding: This work has been supported by the University of Alicante under the projects GRE17-11, and the Spanish Ministry of Economy and Competitiveness (MINECO), the State Agency of Research (AEI) and the European Funds for Regional Development (FEDER) under projects TEC2017-85244-C2-1-P and TIN2014-55413-C2-2-P, and the Spanish Ministry of Education, Culture and Sport under project PRX17/00439.

Acknowledgments: Many thanks are due to DARES technology for the support to DInSAR elaborations. We would like to thank the Alcoy City Council for providing us with some of the information used in this research and especially to Francisco Muñoz.

Conflicts of Interest: The authors declare no conflict of interest. The funders had no role in the design of the study; in the collection, analyses, or interpretation of data; in the writing of the manuscript, or in the decision to publish the results.

\section{References}

1. Agnesi, V.; Camarda, M.; Conoscenti, C.; Di Maggio, C.; Serena Diliberto, I.; Madonia, P.; Rotigliano, E. A multidisciplinary approach to the evaluation of the mechanism that triggered the Cerda landslide (Sicily, Italy). Geomorphology 2005, 65, 101-116. [CrossRef]

2. Ausilio, E.; Zimmaro, P. Landslide characterization using a multidisciplinary approach. Measurement 2017, 104, 294-301. [CrossRef]

3. Del Soldato, M.; Riquelme, A.; Tomás, R.; De Vita, P.; Moretti, S. Application of structure from motion photogrammetry to multi-temporal geomorphological analyses: Case studies from Italy and Spain. Geogr. Fis. e Din. Quat. 2018, 41, 51-66. [CrossRef]

4. Mantovani, M.; Devoto, S.; Forte, E.; Mocnik, A.; Pasuto, A.; Piacentini, D.; Soldati, M. A multidisciplinary approach for rock spreading and block sliding investigation in the north-western coast of Malta. Landslides 2013, 10, 611-622. [CrossRef]

5. Fressard, M.; Maquaire, O.; Thiery, Y.; Davidson, R.; Lissak, C. Multi-method characterisation of an active landslide: Case study in the Pays d'Auge plateau (Normandy, France). Geomorphology 2016, 270, $22-39$. [CrossRef]

6. Refice, A.; Spalluto, L.; Bovenga, F.; Fiore, A.; Miccoli, M.N.; Muzzicato, P.; Nitti, D.O.; Nutricato, R.; Pasquariello, G. Integration of persistent scatterer interferometry and ground data for landslide monitoring: The Pianello landslide (Bovino, Southern Italy). Landslides 2019, 1-22. [CrossRef]

7. Tomás, R.; Abellán, A.; Cano, M.; Riquelme, A.; Tenza-Abril, A.J.; Baeza-Brotons, F.; Saval, J.M.; Jaboyedoff, M. A multidisciplinary approach for the investigation of a rock spreading on an urban slope. Landslides 2018, 15, 199-217. [CrossRef]

8. Grandjean, G.; Pennetier, C.; Bitri, A.; Meric, O.; Malet, J.-P. Caractérisation de la structure interne et de l'état hydrique de glissements argilo-marneux par tomographie géophysique: 1'exemple du glissement-coulée de Super-Sauze (Alpes du Sud, France). Comptes Rendus Geosci. 2006, 338, 587-595. [CrossRef]

9. Jongmans, D.; Bièvre, G.; Renalier, F.; Schwartz, S.; Beaurez, N.; Orengo, Y. Geophysical investigation of a large landslide in glaciolacustrine clays in the Trièves area (French Alps). Eng. Geol. 2009, 109, 45-56. [CrossRef] 
10. Caris, J.P.T.; Van Asch, T.W.J. Geophysical, geotechnical and hydrological investigations of a small landslide in the French Alps. Eng. Geol. 1991, 31, 249-276. [CrossRef]

11. Schmutz, M.; Albouy, Y.; Guérin, R.; Maquaire, O.; Vassal, J.; Schott, J.-J.; Descloîtres, M. Joint Electrical and Time Domain Electromagnetism (TDEM) Data Inversion Applied to the Super Sauze Earthflow (France). Surv. Geophys. 2000, 21, 371-390. [CrossRef]

12. Lapenna, V.; Lorenzo, P.; Perrone, A.; Piscitelli, S.; Rizzo, E.; Sdao, F. 2D electrical resistivity imaging of some complex landslides in Lucanian Apennine chain, southern Italy. GEOPHYSICS 2005, 70, B11-B18. [CrossRef]

13. Méric, O.; Garambois, S.; Malet, J.-P.; Cadet, H.; Guéguen, P.; Jongmans, D. Seismic noise-based methods for soft-rock landslide characterization. Bull. la Soc. Geol. Fr. 2007, 178, 137-148. [CrossRef]

14. Cascini, L.; Peduto, D.; Pisciotta, G.; Arena, L.; Ferlisi, S.; Fornaro, G. The combination of DInSAR and facility damage data for the updating of slow-moving landslide inventory maps at medium scale. Nat. Hazards Earth Syst. Sci. 2013, 13, 1527-1549. [CrossRef]

15. Ferlisi, S.; Peduto, D.; Gullà, G.; Nicodemo, G.; Borrelli, L.; Fornaro, G. The Use of DInSAR Data for the Analysis of Building Damage Induced by Slow-Moving Landslides. In Engineering Geology for Society and Territory_Volume 2; Springer International Publishing: Cham, 2015; pp. 1835-1839.

16. Antonello, G.; Casagli, N.; Farina, P.; Leva, D.; Nico, G.; Sieber, A.J.; Tarchi, D. Ground-based SAR interferometry for monitoring mass movements. Landslides 2004, 1, 21-28. [CrossRef]

17. Tessitore, S.; Di Martire, D.; Calcaterra, D.; Infante, D.; Ramondini, M.; Russo, G. Multitemporal synthetic aperture radar for bridges monitoring. In Proceedings of the Proceedings of SPIE-The International Society for Optical Engineering, Gdansk, Poland, 2017; p. 10431C.

18. Infante, D.; Di Martire, D.; Confuorto, P.; Tessitore, S.; Ramondini, M.; Calcaterra, D. Differential SAR interferometry technique for control of linear infrastructures affected by ground instability phenomena. Int. Arch. Photogramm. Remote Sens. Spat. Inf. Sci. 2018, XLII-3/W4, 251-258. [CrossRef]

19. Barbarella, M.; Fiani, M. Monitoring of large landslides by Terrestrial Laser Scanning techniques: Field data collection and processing. Eur. J. Remote Sens. 2013, 46, 126-151. [CrossRef]

20. Wang, G.; Joyce, J.; Phillips, D.; Shrestha, R.; Carter, W. Delineating and defining the boundaries of an active landslide in the rainforest of Puerto Rico using a combination of airborne and terrestrial LIDAR data. Landslides 2013, 10, 503-513. [CrossRef]

21. Ciampalini, A.; Raspini, F.; Frodella, W.; Bardi, F.; Bianchini, S.; Moretti, S. The effectiveness of high-resolution LiDAR data combined with PSInSAR data in landslide study. Landslides 2016, 13, 399-410. [CrossRef]

22. Szulwic, J.; Tysiąc, P.; Wojtowicz, A. Coastal Cliffs Monitoring and Prediction of Displacements Using Terrestial Laser Scanning. In Proceedings of the 2016 Baltic Geodetic Congress (Geomatics); Baltic Geodetic Congress, Gdansk, Poland, 2-4 June 2016.

23. Crepaldi, S.; Zhao, Y.; Lavy, M.; Amanzio, G.; Suozzi, E.; De Maio, M. Landslide analysis by multi-temporal terrestrial laser scanning (TLS) data: The Mont de la Saxe landslide. Rend. Online Della Soc. Geol. Ital. 2015, 35, 92-95. [CrossRef]

24. Nikolakopoulos, K.; Kavoura, K.; Depountis, N.; Kyriou, A.; Argyropoulos, N.; Koukouvelas, I.; Sabatakakis, N. Preliminary results from active landslide monitoring using multidisciplinary surveys. Eur. J. Remote Sens. 2017, 50, 280-299. [CrossRef]

25. Othman, Z.; Wan, A.W.A.; Anuar, A. Evaluating the performance of GPS survey methods for landslide monitoring at hillside residential area: Static vs rapid static. In Proceedings of the 2011 IEEE 7th International Colloquium on Signal Processing and its Applications, Penang, Malaysia, 4-6 March 2011; pp. 453-459. [CrossRef]

26. Notti, D.; Galve, J.P.; Mateos, R.M.; Monserrat, O.; Lamas-Fernández, F.; Fernández-Chacón, F.; Roldán-García, F.J.; Pérez-Peña, J.V.; Crosetto, M.; Azañón, J.M. Human-induced coastal landslide reactivation. Monitoring by PSInSAR techniques and urban damage survey (SE Spain). Landslides 2015, 12, 1007-1014. [CrossRef]

27. Del Soldato, M.; Bianchini, S.; Calcaterra, D.; De Vita, P.; Di Martire, D.; Tomás, R.; Casagli, N. A new approach for landslide-induced damage assessment. Geomatics, Nat. Hazards Risk 2017, 8, 1524-1537. [CrossRef]

28. Del Soldato, M.; Di Martire, D.; Bianchini, S.; Tomás, R.; De Vita, P.; Ramondini, M.; Casagli, N.; Calcaterra, D. Assessment of landslide-induced damage to structures: The Agnone landslide case study (southern Italy). Bull. Eng. Geol. Environ. 2018, 1-22. [CrossRef] 
29. Almela, A.; Gómez, E.; Quintero, I.; Mansilla, H. Mapa Geológico de España, hoja de Alcoy; Servicio de publicaciones del Ministerio de Industria, Ed.: Madrid, Spain, 1975.

30. Moseley, F.; Cuttell, J.C.; Lange, E.W.; Stevens, D.; Warbrick, J.R. Alpine tectonics and diapiric structures in the Pre-Betic zone of southeast Spain. J. Struct. Geol. 1981, 3, 237-251. [CrossRef]

31. Delgado, J.; Peláez, J.A.; Tomás, R.; López-Casado, C.; Doménech, C.; Estévez, A.; Cuenca, A.; Henares, J. Susceptibilidad a movimientos de ladera inducidos por terremotos en Alcoy (Alicante) y sectores adyacentes. Geo - Temas 2004, 6, 285-288.

32. Delgado, J.; Peláez, J.A.; Tomás, R.; Estévez, A.; López Casado, C.; Doménech, C.; Cuenca, A. Evaluación de la susceptibilidad de las laderas a sufrir inestabilidades inducidas por terremotos. Aplicación a la cuenca de drenaje del río Serpis (provincia de Alicante). Rev. la Soc. Geológica España 2006, 19, 197-218.

33. IGME. Mapa geotécnico y de riesgos geológicos para la ordenación urbana de Alcoy: Mapa de riesgos geologicos E. 1/25.000, 1/2.500, 1/1000: Mapa geotecnico E. 1/25.000, 1/5.000; Instituto, Geoló gico y Minero de, Españ a., Direcció n de Aguas, Subterrá neas y, Geotecnia, Ed.; Servicio de publicaciones del Ministerio de Industria: Madrid, Spain, 1984.

34. Miśkiewicz, M.; Mitrosz, O.; Brzozowski, T. Preliminary Field Tests and Long-Term Monitoring as a Method of Design Risk Mitigation: A Case Study of Gdańsk Deepwater Container Terminal. Polish Marit. Res. 2017, 24. [CrossRef]

35. Miśkiewicz, M.; Pyrzowski, Ł.; Wilde, K.; Mitrosz, O. Technical Monitoring System for a New Part of Gdańsk Deepwater Container Terminal. Polish Marit. Res. 2017, 24, 149-155. [CrossRef]

36. TYPSA. Inestabilidad en el puente de acceso al polígono Santiago Payá y Sembenet, Alcoy (Alicante), Unpublished work. 2012.

37. Reynolds. An Introduction to Applied and Environmental Geophysics; Wiley, Ed.: Chichester, UK, 1997.

38. Blanco-Sànchez, P.; Mallorquí, J.J.; Duque, S.; Monells, D. The Coherent Pixels Technique (CPT): An Advanced DInSAR Technique for Nonlinear Deformation Monitoring. In Earth Sciences and Mathematics; Birkhäuser Basel: Basel, Switzerland, 2008; pp. 1167-1193.

39. Mora, O.; Mallorqui, J.J.; Broquetas, A. Linear and nonlinear terrain deformation maps from a reduced set of interferometric sar images. IEEE Trans. Geosci. Remote Sens. 2003, 41, 2243-2253. [CrossRef]

40. Leica Geosystems AG. Leica ScanStation C10 Data Sheet; Leica Geosystems AG: Heerbrugg, Switzerland, 2011.

41. Lague, D.; Brodu, N.; Leroux, J.J. Accurate 3D comparison of complex topography with terrestrial laser scanner: Application to the Rangitikei canyon (NZ). ISPRS J. Photogramm. Remote Sens. 2013, 82, 10-26. [CrossRef]

42. Notti, D.; Davalillo, J.C.; Herrera, G.; Mora, O. Natural Hazards and Earth System Sciences Assessment of the performance of X-band satellite radar data for landslide mapping and monitoring: Upper Tena Valley case study. Hazards Earth Syst. Sci 2010, 10, 1865-1875. [CrossRef]

43. Plank, S.; Singer, J.; Minet, C.; Thuro, K. Pre-survey suitability evaluation of the differential synthetic aperture radar interferometry method for landslide monitoring. Int. J. Remote Sens. 2012, 33, 6623-6637. [CrossRef]

44. Esposito, G.; Sacchi, M.; Srl, G.; Somma, R. Multitemporal monitoring of a coastal landslide through SFM-derived point cloud comparison. Photogramm. Rec. 2017, 32, 459-479. [CrossRef]

45. California Department of Transportations. Total Station Survey System (TSSS) Survey Specifications. In Surveys Manual; California Department of Transportations: Sacramento, CA, USA, 2007.

46. Jongmans, D.; Garambois, S. Geophysical investigation of landslides: A review. Bull. la Soc. Geol. Fr. 2007, 178, 101-112. [CrossRef]

(C) 2019 by the authors. Licensee MDPI, Basel, Switzerland. This article is an open access article distributed under the terms and conditions of the Creative Commons Attribution (CC BY) license (http://creativecommons.org/licenses/by/4.0/). 